\title{
Metabolism and feeding of mesozooplankton in the eastern Mediterranean (Hellenic coastal waters)
}

\author{
Epaminondas D. Christou ${ }^{1, *}$, Maria Moraitou-Apostolopoulou ${ }^{2}$ \\ ${ }^{1}$ National Centre for Marine Research, Agios Kosmas, Hellinikon, GR-16604 Athens, Greece \\ ${ }^{2}$ Zoological Laboratory, University of Athens, Panepistimiopolis, GR-15784 Athens, Greece
}

\begin{abstract}
Respiration, ammonium and phosphate excretions and phytoplankton consumption of mesozooplankton were examined biweekly in a coastal area of the eastern Mediterranean from January 1989 to January 1990. Taking into account the ambient temperature, the metabolic rates estimated (4 to $31.2 \mu \mathrm{l} \mathrm{O}_{2} \mathrm{mg}^{-1} \mathrm{dw} \mathrm{h} \mathrm{h}^{-1}, 0.4$ to $3.5 \mu \mathrm{g} \mathrm{NH}_{4}-\mathrm{N} \mathrm{mg}^{-1} \mathrm{dw} \mathrm{h} \mathrm{h}^{-1}$ and 0.1 to $0.6 \mu \mathrm{g} \mathrm{PO}_{4}-\mathrm{P} \mathrm{mg}^{-1} \mathrm{dw} \mathrm{h}^{-1}$ ) were lower than those reported for the western Mediterranean, which might be related to the higher oligotrophy in the eastern Mediterranean. Maxima for these metabolic rates and that for zooplankton community respiration ( $7 \mathrm{mg} \mathrm{O} \mathrm{O}^{-3} \mathrm{~d}^{-1}$ ) were all observed during the period of higher temperatures; some degree of acclimation was also inferred and this may be attributed to the high abundance of cladocerans in the summer. Simple and multiple regression models, the latter based on stepwise variable selection, suggested that temperature was the most significant variable affecting zooplankton metabolism. Body weight and population composition were also important variables. Feeding activity, sometimes showing an increase with food concentration, seemed to increase metabolic rate, but temperature may mask this effect. The low O:N ratio indicated a protein-oriented metabolism. Furthermore, the O:N, N:P and O:P fluctuations indicated a dissimilarity in zooplankton dietary pattern, probably due to the low phytoplankton levels and differing exploitation of other supplementary food sources. The results stress the importance of temperature, rather than food or other factors, for zooplankton metabolism in coastal areas of the oligotrophic eastern Mediterranean, which during summer is comparable to oligotrophic tropical seas.
\end{abstract}

KEY WORDS: Metabolism - Respiration - Excretion · Feeding · Mesozooplankton Coastal area Eastern Mediterranean A Annual cycle - Saronikos

\section{INTRODUCTION}

Energy consumption and energy contribution to vital functions of an organism are expressed by the equation $I=G+R+F+U$, relating the energy from food consumption $(I)$ with that required for growth and reproduction $(G)$, respiration $(R)$, egestion $(F)$ and excretion $(U)$. Particularly for zooplankton, respiratory losses may account for up to $60 \%$ of the obviously ingested energy (Green 1975, Sarvala et al. 1981). The assessment of this loss gives information fundamental for estimating minimum food requirement (Lampitt \& Gamble 1982), production rate, and feeding rate (Ikeda \& Motoda 1978). Hence, knowledge of the energetics of metabolism and its relationships to environ-

•E-mail: nondas@edp.ncmr.ariadne-t.gr mental factors can significantly contribute to the understanding of factors which control zooplankton production.

Evaluating the role of zooplankton in the flow of matter and energy is often complicated by the diversity of species constituting the zooplankton population. The results for some selected species can hardly be extended to the entire community; on the other hand, global experiments are often difficult to interpret because some individuals can act as predators and because the intake or uptake flow rates of energy can differ according to the specific composition of the population or the size of organisms.

Zooplankton can excrete considerable amounts of dissolved nitrogen and phosphorus; this regeneration may stimulate phytoplankton growth, possibly balancing the loss of cells through grazing (Lehman 1980 , 
Sterner 1986) and possibly favouring certain phytoplankton taxa over others (Elser et al. 1988, Vanni \& Findlay 1990). If zooplankton excrete $\mathrm{N}$ and $\mathrm{P}$ at a ratio different from that of the particles in the water, grazing coupled with excretion may shift the balance of nutrient limitation from $\mathrm{P}$ to $\mathrm{N}$ or vice versa (Elser et al. 1988).

In general, studies of temporal variation in metabolism of marine zooplankton are very few. Moreover, to our knowledge, studies on annual cycles of metabolic activity on a biweekly or similar basis are lacking. This is probably due to difficulties in interpreting the results from mixed-species populations in changing environments together with methodological problems. Particularly, in the eastern Mediterranean Sea information on zooplankton metabolic activity is practically absent. Saronikos Gulf (Gulf of Athens), a semienclosed area of the SW Aegean Sea, constitutes the most important, both from a social and economic point of view, part of the Hellenic Seas, and it is therefore the best-studied gulf. Previous studies on zooplankton of the area have been largely concerned with species composition and distribution patterns (MoraitouApostolopoulou 1969, 1974, 1977, Christou 1990), pollution impacts (Moraitou-Apostolopoulou 1974, 1976, Moraitou-Apostolopoulou \& Kiortsis 1976) and the biology of the dominant copepod Acartia clausi (Moraitou-Apostolopoulou \& Verriopoulos 1976, 1980, Christou \& Verriopoulos 1993a, b)

Metabolism, in terms of respiration, ammonium and phosphate excretions, and the phytoplankton consumption of mesozooplankton were examined in a coastal area of the oligotrophic eastern Mediterranean (Azov 1991, Christou \& Verriopoulos 1993a). The objectives of this study were to describe levels and seasonal variations of metabolic and feeding activities on a regular basis throughout 1 annual cycle and to analyze their relationships with exogenous and endogenous factors, trying to overcome the methodological problems emerging from the use of mixed zooplankton.

\section{MATERIALS AND METHODS}

This study was carried out biweekly from January 1989 to January 1990. Samples were always taken at the same time of day from a station (about $12 \mathrm{~m}$ depth) in the coastal eastern Saronikos Gulf, characterized as a meso-oligotrophic area (see Christou \& Verriopoulos 1993a) Temperature, oxygen and water samples for salinity, ammonium, phosphates and chlorophyll a determinations were taken from 1, 5 and $10 \mathrm{~m}$ depth using a 21 Hydrobios water sampler equipped with a Hydrobios thermometer. Oxygen, determined by an electrode (YSI oxymetre) and checked for accuracy with simultaneous determinations by the Winkler method, was almost always at saturation (Christou unpubl. data). Nutrient samples were stored at $-20^{\circ} \mathrm{C}$ and analysed within 1 wk. Ammonium and phosphates were determined following Liddicoat et al. (1975) and Strickland \& Parsons (1972), respectively.

A $200 \mu \mathrm{m}$ net with a $45 \mathrm{~cm}$ diameter (Tranter \& Smith 1968), equipped with a Hydrobios flowmeter and towed obliquely from bottom to the surface, was used for zooplankton sampling In order to minimize physical damage to the living zooplankton specimens, a 31 polyethylene bucket (Omori \& Ikeda 1984) was fitted to the cod end of the net. Samples were immediately transferred into a 15 l container, and diluted with water from the same area. Special care was taken in handling and transporting the zooplankton to the laboratory as well as in keeping a constant temperature. The samples were preserved in $4 \%$ buffered formalin (Omori \& Ikeda 1984) and analyzed quantitatively and qualitatively under a Nikon stereoscope $(\times 50)$. Subsamples $(1 / 2$ of the total) were used for biomass determination (Omori \& Ikeda 1984).

Experiments were carried out in a constant-temperature room at in situ temperature $\left(+0.5^{\circ} \mathrm{C}\right)$ from January 1989 to January 1990. Mixed zooplankton was used in with-food and without-food conditions. It has been suggested that such experiments should be conducted over $24 \mathrm{~h}$ periods to overcome diurnal variations and minimize organisms' interactions (Le Borgne 1979). In the present study, preliminary experiments showed that 20 to $24 \mathrm{~h}$ was the minimum period for detectable differences.

In each experiment, respiration, excretion and phytoplankton consumption rates as well as population composition and biomass were determined. In order to enhance the reliability and comparability of the results the experimental design was based on (1) a sufficient number of replicates and (2) accurate and strictly identical experimental procedures. Overall, 24 out of a total of 27 experiments were considered to be successful, although, depending on the condition of the zooplanktion, some replicates were excluded from the calculations.

Gelatinous and carnivorous groups as well as specimens that were dead or in poor condition were removed. The sea water, collected at the same time, was separated as follows: (1) water containing natural food (passed through a $64 \mu \mathrm{m}$ mesh for the removal of eggs, animals and large phytoplankton cells) and (2) water without food (filtered through a $0.6 \mu \mathrm{m}$ GF/F glass fiber filter and carefully re-aerated). Within $2 \mathrm{~h}$ of collection, zooplankton, from 100 to $200 \mathrm{ml}$ (depending on the zooplankton abundance) randomly 
taken subsamples, were introduced into $600 \mathrm{ml}$ bottles. Three additional subsamples (at the beginning, middle and end of the experimental series) were preserved for identification of the population. In order to obtain detectable and reproducible variations in oxygen and excretion, zooplankton density in the bottles was higher than in the environment, ranging at levels (ca 200 to 400 ind. $\mathrm{l}^{-1}$ ) judged as acceptable in such experiments (Razouls 1972, Schneider 1990). All bottles were stoppered without trapping air bubbles and placed in the dark for 20 to $24 \mathrm{~h}$ at in situ temperature to prevent primary production. For each experiment 24 bottles (12 with food and 12 without food; for every 2 bottles there was 1 control without zooplankton) were used. The bottles, suspended in groups of 3 by an apparatus

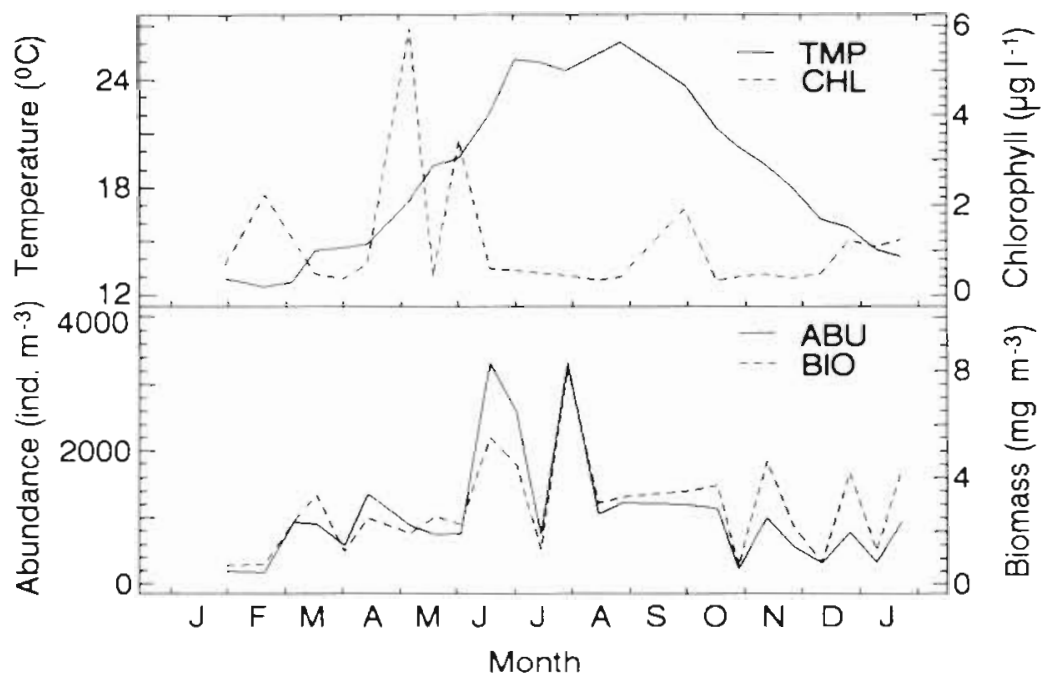

Fig. 1 Water temperature (TMP, $\left.{ }^{\circ} \mathrm{C}\right)$, chlorophyll a (CHL, $\left.\mu \mathrm{g} \mathrm{l}^{-1}\right)$, mesozooplankton abundance $\left(\mathrm{ABU}\right.$, ind. $\mathrm{m}^{-3}$ ) and biomass $\left(\mathrm{BIO}, \mathrm{mg} \mathrm{dw} \mathrm{m}^{-3}\right), 30 \mathrm{Jan}$ uary 1989 to 22 January 1990. Temperature and chlorophyll averaged over the water column (zooplankton from bottom to surface) especially designed for these experiments, were subjected to a compound movement (horizontally and vertically) in order to prevent possible accumulation and settling of phytoplankton, as well as to more or less simulate environmental conditions.

The samples for oxygen, ammonium, phosphate and phytoplankton determination from experimental and control bottles were siphoned through a $200 \mu \mathrm{m}$ mesh in order to retain the organisms in the bottles. Zooplankton were transferred by filtration on precombusted and preweighed GF/F glass fiber filters and analyzed as for zooplankton biomass. Dissolved oxygen was measured using a magnetic stirrer and a YSI electrode according to Gaudy \& Boucher (1983) and Uye \& Yashiro (1988). Ammonium and phosphates, estimated in without-food bottles only (to avoid possible errors from phytoplankton), were analysed within $3 \mathrm{~d}$ from the time of storage (at $-20^{\circ} \mathrm{C}$ ). Crude phytoplankton analysis (number of cells $1^{-1}$ ) was based on Utermöhl's (1958) method. Rates, calculated from the difference between experimental and control bottles, were expressed as $\mu l \mathrm{O}_{2}$. $\mu \mathrm{g} \mathrm{NH}_{4}-\mathrm{N}, \mu \mathrm{g} \mathrm{PO}_{4}-\mathrm{P}$ and number of cells per mg dry weight of zooplankton per hour. The atomic metabolic ratios $\mathrm{O}: \mathrm{N}$ (consumption/excretion), $\mathrm{N}: \mathrm{P}$ and $\mathrm{O} P$ were also determined.

In order to identify any possible differences between experimental and field populations, classification and ordination techniques (Field et al. 1982) based on relative abundances of species were used. The relationship of metabolism to the various factors was examined by simple and multiple regression analyses, the latter based on stepwise variable selection.

\section{RESULTS}

\section{Environmental data}

The seasonal pattern of the water temperature is shown in Fig. 1. The wind-driven mixing generally did not allow the development of stratified conditions but transient weak layering was present on some occasions (Christou unpubl. data). The annual range of salinity variations fell within about $1 \%$ (Christou \& Christianides unpubl. data). Nutrient values ranged from 0.16 to $1.25 \mu \mathrm{M} \mathrm{NH}_{4}-\mathrm{N} \mathrm{l}^{-1}$ and 0 to $0.38 \mu \mathrm{MPO}_{4}$ $\mathrm{P}^{-1}$ (Christou 1992), which are generally considered normal for the area. The phosphate concentrations were low for a coastal area, especially during the summer (Christou 1992). Phytoplankton biomass, expressed as mean chlorophyll a of the total water column, peaked in May while some high values were recorded in February, June and October (Fig. 1). Data on other sources of available carbon as potential food are lacking. Maximal zooplankton abundance and biomass, observed in June and July (Fig. 1), were mainly attributable to the high contribution of cladocerans. No direct relation between zooplankton biomass and chlorophyll was discovered.

\section{Experimental populations}

For the study of the structure of the experimental populations (gross features in Fig 2), a total of 72 subsamples $(24 \times 3)$ were analysed. Copepods were 

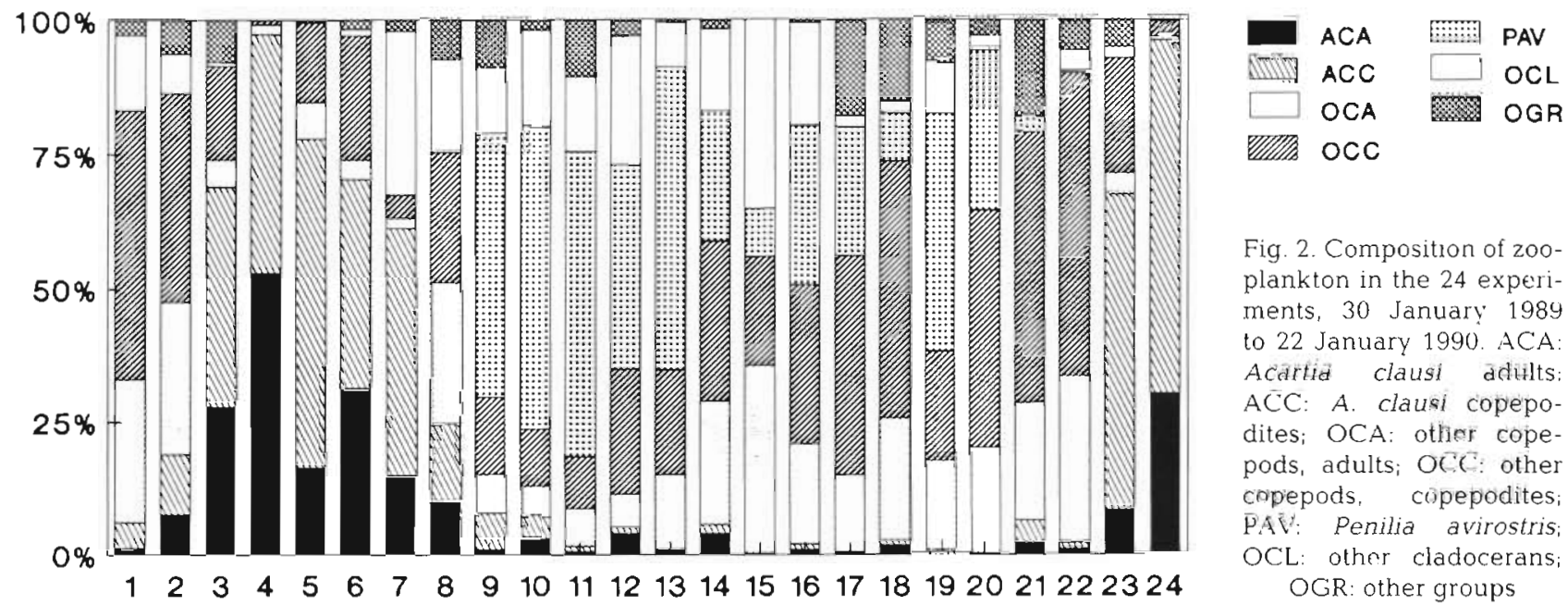

Fig. 2. Composition of zooplankton in the 24 experiments, 30 January 1989 to 22 January 1990 . ACA Acartia clausi adults; ACC: A. clausi copepodites; OCA: other copepods, adults; OCC: other copepods, copepodites; PAV: Penilia avirostris; OCL: other cladocerans; OGR: other groups

the dominant group, representing on average $67 \%$ of the total count. Juveniles comprised $64 \%$ of the copepods. Acartia clausi, a copepod commonly dominant in local bays and coastal areas, formed up to $96 \%$ of the total zooplankton population during the cold period (January to May) and represented $26 \%$ of the total on average. The juveniles of Clausocalanus spp. and Paracalanus parvus (second in abundance among the copepods) were much more abundant than the adults. Cladocerans, (second group in abundance) attaining great numbers during the warm period (June to October), constituted $28 \%$ of the total Penilia avirostris (18\% of the total) showed the highest abundance, attaining great numbers between June and August. Other groups comprised less than $5 \%$ of the zooplankton.
Multivariate analysis (on data analyzed down to species level for copepods and cladocerans) revealed that the structure of experimental populations was very similar to that in the field (Fig. 3); the removal of the organisms did not significantly alter the population structure. Therefore, the experimental populations sufficiently represent those in the field, allowing the estimated rates to be applied to the field. A seasonality in zooplankton communities ( 3 groups: winter, winterspring, summer-autumn) and a circular ordination of the points corresponding to the annual cycle was evident (Fig. 3).

The mean dry weight of specimens (irrespective of species) is shown in Fig. 4. Based on population biomass and abundance data, it reflected changes in size composition of the experimental populations. During summer, when cladocerans attained high numbers, mean weights were about 3 -fold lower.

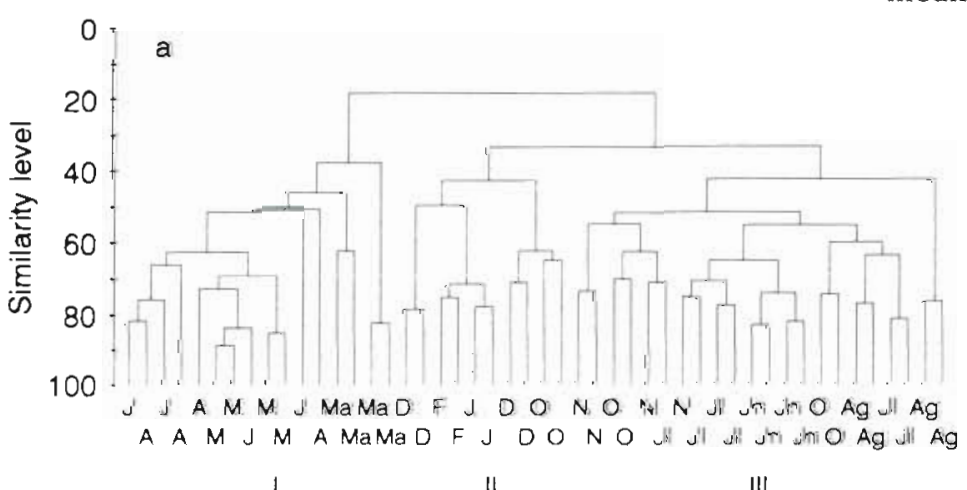

Fig. 3. (a) Dendrogram and (b) multidimensional scalıng (MDS) plot for the 24 experimental and the 24 field concurrent zooplankton populations, 30 January 1989 to 22 January 1990. For the MDS plot the concurrent pairs (expenmental - field) are encircled. J: January; F: February; M: March; A: April; Ma: May; Jn: June; Jl: July; Ag: August; S: September; O: October; N: November; D: December. I: winter-spring; II: winter; and III: summer-autumn

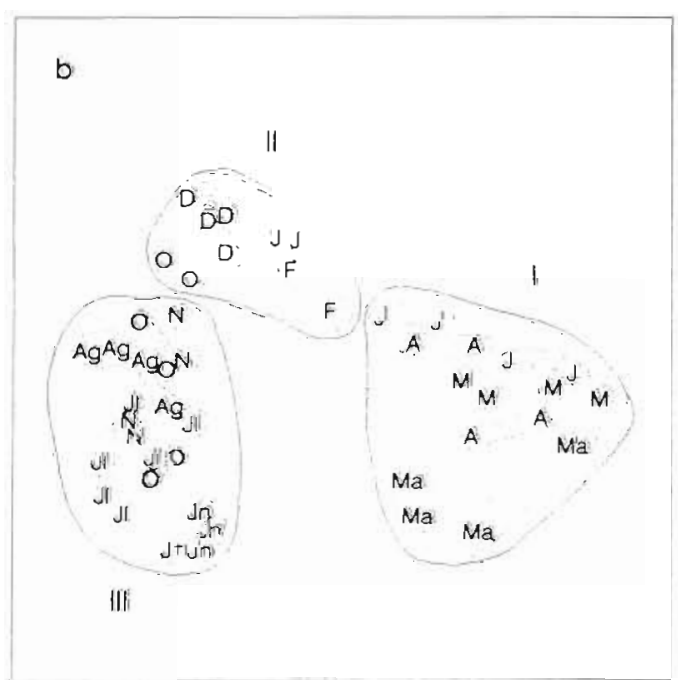




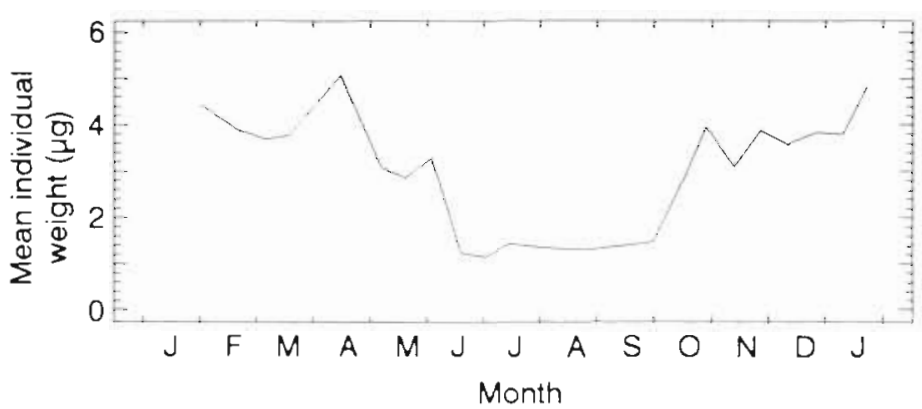

Fig. 4. Mean individual dry weight $(\mu \mathrm{g})$ for the experimental zooplankton populations, 30 January 1989 to 22 January 1990 tions ranging from 27 to $747 \times 10^{3}$ cells $1^{-1}$. Note that in some experiments with phytoplankton concentrations $>20 \times 10^{3}$ cells $1^{-1}$ (e.g. 20 Feb 1989, 13 Nov 1989, 27 Dec 1989; Fig 6), the consumption rates were 20 to $40 \%$ lower than those at $13 \times 10^{3}$ cells $1^{-1}$ (20 Jun 1989. 2 Oct 1989; Fig. 6); this fact might be related to different phytoplankton species prevailing each time and/or additional food, such as small flagellates and other suspended material.

The respiration of the mesozooplankton community (respiration rate applied to the field) ranged from 0.1 to $7.0 \mathrm{mg} \mathrm{O} \mathrm{m}^{-3} \mathrm{~d}^{-1}$, with highest values during July (Fig. 7).

\section{Respiration, excretion and feeding rates}

The respiration rate, ranging from 4 to $31.2 \mathrm{\mu l} \mathrm{O}_{2} \mathrm{mg}^{-1} \mathrm{dw} \mathrm{h} \mathrm{h}^{-1}$ (mean $\pm \mathrm{SD}$ : $11.88 \pm 8.00)$ in the presence of food (Fig. 5a), seemed to follow closely the temperature variations (Figs. 1 \& 5a; Table 1). In early summer a rapid rise in temperature resulted in an almost 3-fold increase in respiration rate (early July) which, however, soon declined by about $25 \%$ (mid-July), although the same high temperatures prevailed; this might be explained by acclimation phenomena (Andrew 1985) and, possibly, by the change in phytoplankton concentration (Fig. 6)

Respiration in without-food treatments (Fig. 5b), ranging from 3.2 to $27.6 \mu \mathrm{l} \mathrm{O}_{2}$ $\mathrm{mg}^{-1} \mathrm{dw} \mathrm{h}^{-1}$ (mean 10.73 \pm 7.68), showed a pattern similar to respiration in with-food treatments (Fig, 5a,b), although values in all cases were lower. The excretion rates of ammonium and phosphates, varying between 0.4 and $3.5 \mu \mathrm{g} \mathrm{NH}_{4}-\mathrm{N} \mathrm{mg}^{-1} \mathrm{dw} \mathrm{h}^{-1}$ (mean $1.40 \pm$

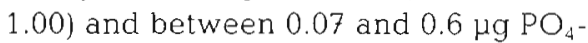
$\mathrm{P} \mathrm{mg}^{-1} \mathrm{dw} \mathrm{h}^{-1}$ (mean 0.20 \pm 0.13 ), respectively, showed trends which were similar to one another (Fig. 5c, d). The excretion rates exhibited seasonal fluctuation patterns more or less similar to those of respiration rates.

The phytoplankton consumption rate (Fig 5e) did not show any distinct pattern but rather followed the fluctuations of the initial phytoplankton concentrations (Fig. 6). The maximum consumption rate was about $7.5 \times 10^{3}$ cells $\mathrm{mg}^{-1}$ $\mathrm{dw} \mathrm{h}^{-1}$ with phytoplankton concentra-

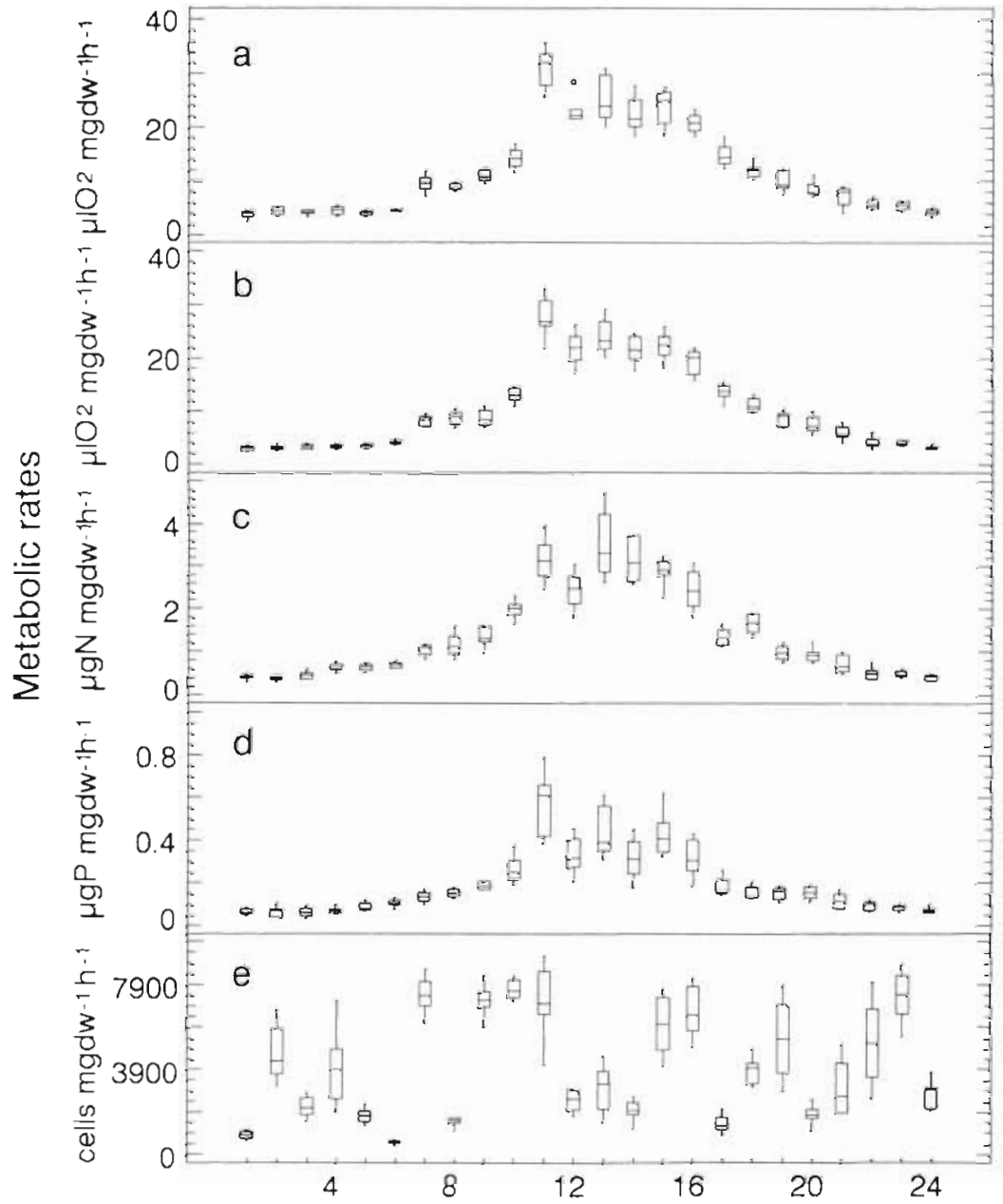

Fig. 5. Box-whisker plots of rates measured in the 24 experiments, 30 January 1989 to 22 January 1990. (a) Respiration with food $\left(\mu l \mathrm{O}_{2} \mathrm{mg}^{-1} \mathrm{dw} \mathrm{h}^{-1}\right.$ ); (b) respiration without food $\left(\mu \mathrm{l} \mathrm{O}_{2} \mathrm{mg}^{-1} \mathrm{dw} \mathrm{h}^{-1}\right)$; (c) nitrogen excretion $\left(\mu \mathrm{g} \mathrm{NH}_{4}-\mathrm{N}\right.$ $\mathrm{mg}^{-1} \mathrm{dw} \mathrm{h} \mathrm{h}^{-1}$ ); (d) phosphate excretion ( $\mu \mathrm{g} \mathrm{PO}_{4}-\mathrm{P} \mathrm{mg}^{-1} \mathrm{dw} \mathrm{h}^{-1}$ ); (e) phytoplankton consumption (cells $\mathrm{mg}^{-1} \mathrm{dw} \mathrm{h}^{-i}$ ). The central box encloses the middle $50 \%$ of the data, the horizontal line inside the box represents the median, the vertical line (whisker) represents the range of $75 \%$ of the data, whereas unusual values occur as separate points 


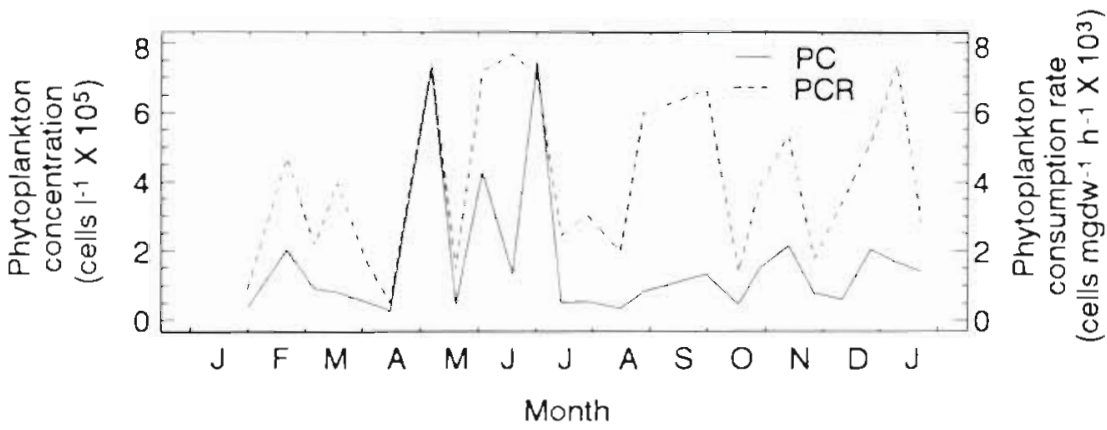

Fig. 6. Phytoplankton concentration ( $\mathrm{PC}$, cells $\mathrm{I}^{-1}$ ) and phytoplankton consumption rate (PCR, cells $\mathrm{mg}^{-1} \mathrm{dw} \mathrm{h}^{-1}$ ) in the experiments, 30 January 1.989 to 22 January 1990
Table 1. Statistically significant regressions $[\log y=a( \pm \mathrm{SE})+b( \pm \mathrm{SE}) \log x]$ between metabolism [weight-specific respiration rates in absence and presence of food ( $R A$ and $\left.R P, \mu \mathrm{O}_{2} \mathrm{mg}^{-1} \mathrm{dw}^{-1}\right)$, weight-specific excretion rates $\left(\mathrm{NH}_{4}\right.$ and $\left.\mathrm{PO}_{3}, \mu \mathrm{g} \mathrm{m \textrm {mg } ^ { - 1 }} \mathrm{dw} \mathrm{h}^{-1}\right)$, and mesozooplankton community respiration $\left[Z C R\right.$, $\left.\left.\mathrm{mg} \mathrm{O}_{2} \mathrm{~m}^{-3} \mathrm{~d}^{-1}\right)\right]$ and various factors as independent variables, from 30 January 1989 to 22 January 1990. TMP: temperature $\left({ }^{\circ} \mathrm{C}\right)_{i} I N W$ : mean individual dry weight in experiments $(\mu \mathrm{g})$; COP: copepod population in experiments (\%); CLA: cladoceran population in experiments $(\%) ; A B U$ : zooplankton abundance (ind. $\left.\mathrm{m}^{-3}\right) ; B I O$ : mesozooplankton biomass $\left(\mathrm{mg} \mathrm{m}^{-3}\right)$. For all regressions $\mathrm{n}=24, \mathrm{p}<0.001$

\begin{tabular}{|lrr|}
\hline Regression & \multicolumn{1}{c|}{$R^{2}$} & $F$ \\
\hline $\log R A=-2.86( \pm 0.14)+3.00( \pm 0.11) \log T M P$ & 0.96 & 691.7 \\
$\log R A=1.49( \pm 0.07)-1.31( \pm 0.14) \log I N W$ & 0.80 & 87.3 \\
$\log R A=2.99( \pm 0.37)-1.16( \pm 0.21) \log C O P$ & 0.59 & 32.1 \\
$\log R A=0.47( \pm 0.08)+0.40( \pm 0.06) \log (C L A+1)$ & 0.68 & 47.2 \\
$\log \cap H_{4}=-3.68( \pm 0.17)+2.95( \pm 0.13) \log T M P$ & 0.96 & 499.1 \\
$\log \mathrm{NH}_{4}=0.60( \pm 0.07)-1.29( \pm 0.14) \log I N W$ & 0.79 & 84.2 \\
$\log \mathrm{NH}_{4}=2.02( \pm 0.38)-1.12( \pm 0.21) \log C O P$ & 0.56 & 27.8 \\
$\log \mathrm{NH}_{4}=-0.38( \pm 0.08)+0.37( \pm 0.06) \log (C L A+1)$ & 0.60 & 32.7 \\
$\log P \mathrm{O}_{1}=-3.95( \pm 0.17)+2.51( \pm 0.13) \log T M P$ & 0.94 & 347.5 \\
$\log \mathrm{PO}_{4}=-0.29( \pm 0.06)-1.11( \pm 0.12) \log I N W$ & 0.80 & 87.6 \\
$\log P \mathrm{O}_{4}=1.04( \pm 0.30)-1.02( \pm 0.17) \log C O P$ & 0.64 & 38.4 \\
$\log P \mathrm{O}_{4}=-1.15( \pm 0.07)+0.33( \pm 0.05) \log (C L A+1)$ & 0.62 & 36.6 \\
$\log R P=-2.46( \pm 0.15)+2.73( \pm 0.12) \log T M P$ & 0.96 & 523.8 \\
$\log R P=1.51( \pm 0.06)-1.21( \pm 0.13) \log I N W$ & 0.81 & 92.3 \\
$\log R P=2.92( \pm 0.33)-1.09( \pm 0.18) \log C O P$ & 0.62 & 35.7 \\
$\log R P=0.56( \pm 0.07)+0.37( \pm 0.05) \log (C L A+1)$ & 0.69 & 49.8 \\
$\log Z C R=-5.21( \pm 0.67)+4.04( \pm 0.53) \log T M P$ & 0.73 & 58.5 \\
$\log Z C R=0.71( \pm 0.14)-1.87( \pm 0.28) \log I N W$ & 0.67 & 45.6 \\
$\log Z C R=2.96( \pm 0.60)-1.73( \pm 0.34) \log C O P$ & 0.54 & 25.6 \\
$\log Z C R=-0.68( \pm 0.16)+0.50( \pm 0.12) \log (C L A+1)$ & 0.44 & 17.6 \\
$\log Z C R=-3.81( \pm 0.46)+1.27( \pm 0.16) \log A B U$ & 0.75 & 66.0 \\
$\log Z C R=-0.64( \pm 0.09)+1.42( \pm 0.19) \log B I O$ & 0.72 & 55.8 \\
\end{tabular}

\section{Relationships between metabolism and other variables}

All significant equations (based on the means) found by simple regression analysis are summarized in Table 1. Temperature was the best single predictor of metabolic rates with $\mathrm{R}^{2}$ values ranging from 0.73 to 0.96 . Mean individual weight also strongly affected metabolism $\left(\mathrm{R}^{2}=0.67\right.$ to 0.81$)$. The relative abundances of copepods and cladocerans $\left(R^{2}=0.44\right.$ to 0.69$)$, indicating a population composition effect, as well as the zooplankton abundance and biomass $\left(R^{2}=0.75\right.$, $0.72)$ showed significant relationships with the above dependent variables. In contrast, no statistically significant regression was found between metabolism and phytoplankton cells offered as food or field chlorophyll values (for all cases $\mathrm{p}>0.05$ ).

The calculated equations of the multiple regression models, produced through stepwise variable selection, are presented in Table 2. Temperature, as the most significant variable, and mean individual weight were found to be the best predictors. The copepod relative abundance and zooplankton biomass were also included among the predictors. The estimated rates and respiration of the

Table 2. Stepwise varlable selection $\left[\log y=a( \pm \mathrm{SE})+b_{1}( \pm \mathrm{SE}) \log x_{1}+\ldots+b_{k}( \pm \mathrm{SE}) \log x_{k}, \mathrm{n}=24\right]$ between metabolism $[$ weightspecific respiration rates in absence and presence of food ( $R A$ and $R P)$, weight-specific phosphate excretion rate $\left(\mathrm{PO}_{4}\right)$, and mesozooplankton community respiration $(Z C R)$ ) and various factors as independent variables from 30 January 1989 to 22 January 1990. IMP: temperature; INW: mean individual dry welght in experiments; COP: copepod population in oxperiments (\%); CLA: cladoceran population in experiments (\%), BIO: mesozooplankton biomass. All units as in Table 1 The variables were entered into the models in the order appearing in the equations. Significant at $p<0.001$, except $p<0.05$

\begin{tabular}{|lll|}
\hline Multiple regression & $R^{2}$ & $F$ \\
\hline $\log R A=-2.24( \pm 0.31)+2.59( \pm 0.21) \log T M P-0.23( \pm 0.1)^{\bullet} \log I N W$ & 0.97 & 411.1 \\
$\log P O_{4}=-3.2( \pm 0.38)+2.2( \pm 0.19) \log T M P-0.2( \pm 0.09)^{*} \log C O P$ & 0.95 & 204.7 \\
$\log R P=-1.75( \pm 0.31)+2.26( \pm 0.22) \log T M P-0.26( \pm 0.1) \cdot \log I N M$ & 0.97 & 327.9 \\
$\log Z C R=-3.22( \pm 0.31)+2.28( \pm 0.21) \log T M P+0.94( \pm 0.04) \log B I O-0.29( \pm 0.1) \cdot \log I N W$ & 0.99 & 667.8 \\
\hline
\end{tabular}




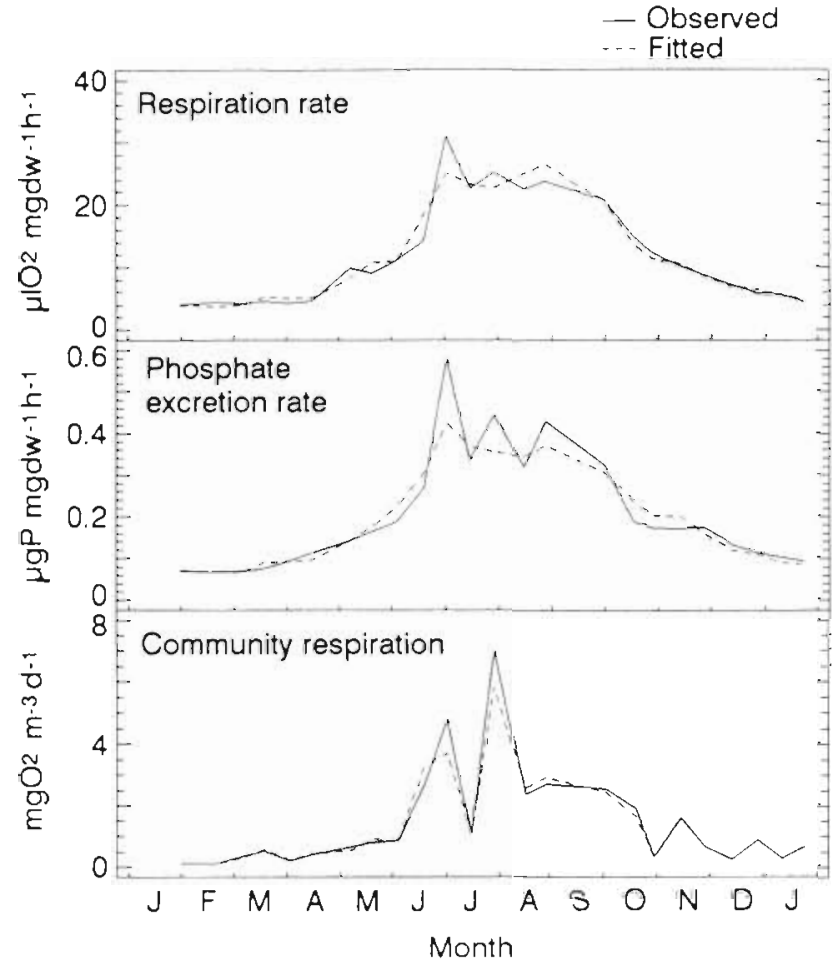

Fig. 7. Observed and fitted values of weight-specific respiration rate with food $\left(\mu \mathrm{O}_{2} \mathrm{mg}^{-1} \mathrm{dw} \mathrm{h} \mathrm{h}^{-1}\right)$, weight-specific phosphate excretion rate $\left(\mu \mathrm{g} \mathrm{PO}_{4}-\mathrm{P} \mathrm{mg}^{-1} \mathrm{dw} \mathrm{h}^{-1}\right)$ and mesozooplankton community respiration ( $\mathrm{mg} \mathrm{O} \mathrm{O}_{2} \mathrm{~m}^{-3} \mathrm{~d}^{-1}$ ), based on the equations of Table 2, 30 January 1989 to 22 January 1990

zooplankton community were compared with those calculated from the multiple regression models showing a good fit (Fig. 7).

\section{Metabolic ratios}

Minimum and maximum values found for the $\mathrm{O}: \mathrm{N}$ ratio were 7.1 and 12.6 respectively (mean $9.64 \pm 1.33$ ); the N:P ratio (mean $14.82 \pm 3.07$ ) ranged from 10.2 to 22.0 , whereas the O:P ratio (mean $140.92 \pm 26.52$ ) varied between 102 and 202 (Fig. 8). All these ratios fluc-

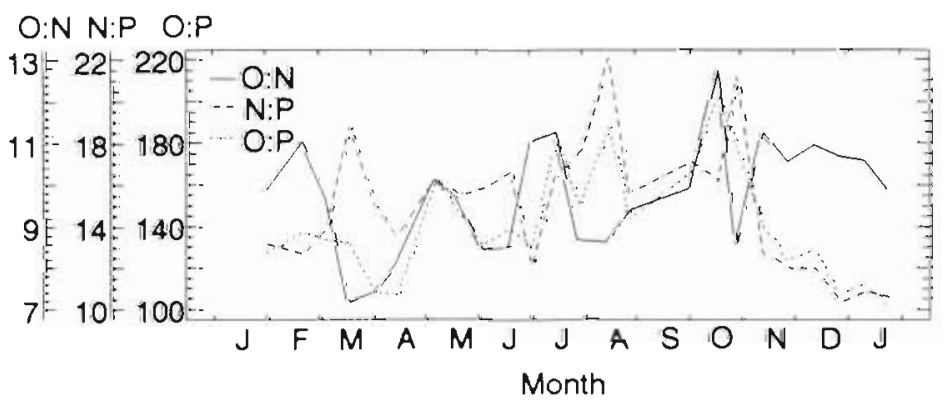

Fig. 8. Fluctuations of O:N, N:P and N:P atomic ratios, 30 January 1989 to 22 January 1990 tuated greatly with month and no distinct pattern was evident (Fig. 8).

\section{DISCUSSION}

The structure of experimental zooplankton populations showed a close agreement with that of natural populations collected at the same time; the exclusion of gelatinous and other carnivorous organisms from zooplankton samples did not alter the in situ picture, due to the low number of carnivores.

Metabolism studies are affected by a number of methodological problems (Omori \& Ikeda 1984). In general, there are different methods for the estimation of zooplankton metabolic rates (e.g. incubation techniques, enzymatic methods), the advantages and disadvantages of which have been discussed elsewhere (e.g. Omori \& Ikeda 1984, Schneider 1990). In incubation bottles, concentrations usually exceed natural densities by several times, which very often leads to crowding effects. On the other hand, if a low number of individuals is used, prolonged incubation is needed and errors may result from starvation. The addition of any kind of food may introduce other errors. As a result, the accuracy of metabolic rates obtained in incubation experiments can hardly be checked (Schneider \& Lenz 1991). In the present study, the use of zooplankton that satisfactorily represents the natural population, along with the use of natural food, should have reduced many possible error sources. Crowding and low oxygen concentrations can affect respiratory rates (Zeiss 1963, Razouls 1972), but only at levels far from those in this experiment (Razouls 1972. Omori \& Ikeda 1984, Schneider 1990). Hence, it is supposed that the measured rates reflect the in situ conditions. On the other hand, possible error sources were kept constant among all experiments, and this gives reliability to the results, especially for ratios and fluctuations within/between measured rates.

In general, it is difficult to compare metabolic rates from different areas, due to (1) scarcity of data, (2) methodolocical problems and (3) lack of ambient temperature information. In the present study the metabolic rates for mixed zooplankton seem to be more or less lower than those reported for the western Mediterranean at $15^{\circ} \mathrm{C}$ (Alcaraz 1988, $5.95 \mu \mathrm{l} \mathrm{O} \mathrm{mg}^{-1} \mathrm{dw} \mathrm{h}^{-1}, 0.37 \mu \mathrm{g}$ $\mathrm{NH}_{4}-\mathrm{N} \mathrm{mg}^{-1} \mathrm{dw} \mathrm{h}{ }^{-1}, 0.18 \mu \mathrm{PO}_{4}-\mathrm{P} \mathrm{mg}^{-1} \mathrm{dw}$ $\mathrm{h}^{-1}$ ) and at $17^{\circ} \mathrm{C}$ (Alcaraz \& Packard 1989; $16.8 \mu \mathrm{l} \mathrm{O}_{2} \mathrm{mg}^{-1} \mathrm{dw} \mathrm{h}^{-1}$ ); this might be related to increasing oligotrophy from the western to the eastern Mediterranean. Moreover, metabolic rates are lower than those reported for a western Mediterranean lagoon (Gaudy 1989; at 6 to $25^{\circ} \mathrm{C}$ from 1.24 to $33.83 \mu \mathrm{g} \mathrm{NH}_{4}-\mathrm{N} \mathrm{mg}^{-1}$ 
$\left.\mathrm{dw} \mathrm{h}^{-1}\right)$ as well as for the adjacent Atlantic Ocean at 14 to $18^{\circ} \mathrm{C}$ (Le Borgne $1973 ; 10.14 \mu \mathrm{O}_{2} \mathrm{mg}^{-1} \mathrm{dw} \mathrm{h}^{-1}$ $0.94 \mu \mathrm{g} \mathrm{NH}_{4}-\mathrm{N} \mathrm{mg}^{-1} \mathrm{dwh} \mathrm{h}^{-1}, 0.19 \mu \mathrm{PO}_{4}-\mathrm{P} \mathrm{mg}^{-1} \mathrm{dw}$ $\left.\mathrm{h}^{-1}\right)$. Note that some of the reported metabolic rates originated from rates per $\mu \mathrm{MN}$ of zooplankton, equating $1 \mathrm{mg}$ dry weight to $7 \mu \mathrm{MN}$ (Margalef \& Vives 1967. Alcaraz 1988). In the present study, the metabolic rates showed similar patterns of variation; similar trends in ammonium and phosphate excretion of zooplankton have been observed in the western Mediterranean (Alcaraz 1988).

Responses of metabolic rates may vary within a range of temperatures (Schatzlein \& Costlow 1978) while stable rates may be encountered for parts of the temperature range (Ranta \& Hakala 1978, Epp \& Lewis 1980). Interpretation of the effect of temperature on the level of metabolic energy is complicated by the many endogenous and environmental factors which may act simultaneously under natural conditions. This fact is more pronounced in natural multi-species populations than single-species laboratory studies. The variation of the respiration rate even among closely related species is considerable (Ikeda \& Skjoldal 1989) and cannot be exclusively explained as a result of difference in the temperature and the size of the organisms (Hamburger \& Boëtius 1987)

In the present study, respiration rates followed changes in the in situ temperature. The regressions showed that temperature (the most significant variable), body mass, and population composition affect zooplankton metabolism; combination of these easily accessible variables gave satisfactory predictions of metabolic rates. The high respiration rate during the warm period is probably due to the cladoceran populations dominating this period; aside from the direct influence of temperature on metabolism, the high participation of cladocerans causes a decrease in the mean individual weight of the zooplankton population. Nevertheless, some degree of acclimation can be inferred, except for periods of more rapid temperature fluctuations leading unacclimated zooplankton to increased metabolic rates (e.g. early July; Figs. 1. \& 5d). The generation time of parthenogenetic cladocerans is shorter than that of copepods, giving the cladocerans more opportunity to acclimate for the same period at the same temperature; a marked dominance by 1 species, in this case Penilia avirostris, will dictate the community metabolic response. The above observations are comparable to those made by Andrew (1985) for a zooplankton community dominated by cladocerans. The fluctuations between copepodite and adult relative abundances could also contribute to respiration rate variations, since ontogenetic stage may influence metabolic rates (Paffenhöfer \& Gardner 1984, Jacobi \& Anger 1985). However, further studies on single- species populations for the evaluation of metabolic rates and contribution of each zooplankton component in the area are necessary. This study is also in agreement with the hypothesis that water temperature and body mass are the 2 major factors governing metabolic level of marine zooplankton (Ikeda 1985).

Food has been repeatedly referred to as a moderator of zooplankton metabolic responses. It is well known that pelagic copepods vary greatly in dietary behaviour, mainly depending on the available food, which makes impossible the classification of a given species into a well-defined category. In this study a selection of organisms with similar food habits, the 'secondary level' of zooplankton, was attempted; a removal of carnivores was undertaken and phytoplankton were considered as the primary food source for the zooplankton. The feeding rate was found to be crudely related to phytoplankton concentration. The lack of such a strong correlation gives some evidence that food other than phytoplankton (small flagellates and/or other suspended material) also affected feeding rate.

In general, respiration rate increases as available food becomes more abundant (Gaudy 1974, Abou Debs 1984, Kiørboe et al, 1985). This is not necessarily true for excretion rates, since it has been found that nauplii or CII copepodites of the copepod Eucalanus pileatus in low-food conditions had higher calculated weight-specific release rates of ammonium than those in high-food conditions (Paffenhöfer \& Gardner 1984). Starvation reduces respiration rates and this effect becomes evident after a certain period of time (e.g Hamburger \& Boëtius 1987). On the other hand, increased feeding activity increases metabolic rates but only after maximum filtering rates are achieved (Kersting \& Van der Leeuw-Leegwater 1976). In the present study respiration rates with food were always higher than those without food, a fact which could be attributed to feeding activity.

No relationship was found between respiration rate and feeding rate (or phytoplankton concentration or chlorophyll). The overriding effect of temperature probably masks the feeding effect. On the other hand, the effect of food was not completely studied since only phytoplankton consumption was taken into account. Zooplankton apparently have developed their capability for utilizing other organic material as supplementary food.

The darly zooplankton excretion (rates applied to the field), in terms of ammonium and phosphate, rose up to 0.049 and $0.003 \mu \mathrm{M} \mathrm{l}^{-1} \mathrm{~d}^{-1}$, respectively (late July; Christou 1992); although the study area is coastal, the phosphate excretion of zooplankton seems to play an important regeneration role in the area during summer, when the lack of phosphates seems to limit phytoplankton (Christou 1992) 
The atomic O:N, N:P and O:P ratios are used as indicators of metabolic substrates (Ikeda 1977). The efficiency of protein or carbohydrate intake would depend not only on potential ability to digest these substrates (activity of enzymes), but also on the quantity of the available food, time necessary for gut transit and seasonal acclimation (Mayzaud \& Poulet 1978, Gaudy \& Boucher 1983). The $\mathrm{O}: \mathrm{N}$ ratio has been considered to be the most useful index to distinguish protein metabolism from carbohydrate and lipid metabolism (lkeda 1977); it has been suggested that it probably reflects the nutritional strategy of the zooplankton rather than what they have recently eaten (Gaudy \& Boucher 1983). It is accepted that values of $O: N<24$ indicate a protein-dominated metabolism (see Omori \& Ikeda 1984). In this study, protein-oriented metabolism was identified in all cases $(O: N$ from 7 to 12$)$, and occasionally (when values of $O: N$ were minimal) metabolized substrate seemed to be exclusively protein; protein metabolism, a situation characteristic of tropical, subtropical and temperate seas (Omori \& Ikeda 1984), implies deviations from herbivory. The strong fluctuations of the metabolic ratios also suggest a dissimilarity in the dietary pattern of zooplankton. The above indications could be related to (1) periods with low phytoplankton levels (periods with food limitation in the area: Christou \& Verriopoulos 1993a, b) and (2) alternative exploitation of food sources in the area.

It can generally be concluded that temperature seems to be the major moderator of zooplankton metabolism in the eastern Mediterranean coastal environment. Summer conditions, characterised by high temperature and small individual weight, lead to a subtropical situation with increased metabolic activity; this situation can be compared to that of the oligotrophic tropical regions characterised by rapid recycling of organic matter (Schneider \& Lenz 1991).

Studying the plankton community respiration in a eutrophic shallow area, Jensen et al. (1990) found that high pelagic respiration rates were associated with formation and collapse of phytoplankton blooms, independent of temperature and the time of the year. Hence, it seems that in eutrophic areas food is the major component triggering high respiration rates as opposed to oligotrophic areas where, according to this study, temperature plays such a role. This fact, resulting also in different seasonal patterns of metabolic rates between the 2 systems, can provide some explanation for the factors controlling the role of the zooplankton compartment in the functioning differentiation among ecosystems.

Acknowledgements. We thank Dr G Verriopoulos for his help in experimental design. We are also grateful to the anonymous reviewers for their useful and constructive criticism.

\section{LITERATURE CITED}

Abou Debs C (1984) Carbon and nitrogen budget of the calanoid copepod Temora stylifera: effect of concentration and composition of food. Mar Ecol Prog Ser 15:213-223

Alcaraz M (1988) Summer zooplankton metabolism and its relation to primary production in the Western Mediterranean. [n: Minas HJ, Nival P (eds) Oceanographie pélagique mediterrannéene. Oceanol Acta (Sp ed) 9:185-191

Alcaraz M, Packard TT (1989) Zooplankton ETS activity and respiration in the Catalan Sea (Western Mediterramean). Scientia mar 53:247-250

Andrew TE (1985) Seasonal variations in the metabolic rates of zooplankton populations in a Thames valley reservoir. Hydrobiologia 127:41-52

Azov Y (1991) Eastern Mediterranean - a marine desert? Mar Pollut Bull 23:225-232

Christou E (1990) Fluctuations of zooplankton, during spring and summer in a coastal area of the Saronikos Gulf. In: Proceedings of the 3rd Hellenic Symposium of Oceanography and Fisheries. National Centre for Marine Research (NCMR), Athens, p 513-520 (in Greek)

Christou $E$ (1992) On the role of mesozooplankton in the regeneration of nutrients in the Saronikos Gulf (Greece) Rapp Comm int Mer Médit 33:170

Christou ED, Verriopoulos GC (1993a) Analysis of the biological cycle of Acartia clausi (Copepoda) in a meso-oligotrophic coastal area of the eastern Mediterranean Sea using time-series analysis. Mar Biol 115:643-651

Christou ED, Verriopoulos GC (1993b) Length, weight and condition factor of Acartia clausi (Copepoda) in the eastern Mediterranean. J mar biol Ass UK 73:343-353

Elser JJ, Elser MM, Mackay NA, Carpenter SR (1988) Zooplankton-mediated transitions between $\mathrm{N}$ - and P-limited algal growth. Limnol Oceanogr 33:1-14

Epp RW, Lewis WM (1980) The nature and ecological significance of metabolic changes during the life history of copepods. Ecology 61:259-264

Field JG, Clark KR, Warwick RM (1982) A practical strategy for analysing multispecies distribution patterns. Mar Ecol Prog Ser 8:37-52

Gaudy R (1974) Feeding four species of pelagic copepods under experimental conditions. Mar Biol 25:125-141

Gaudy R (1989) The role of zooplankton in the nitrogen cycle of a Mediterranean brackish lagoon. Scientia mar 53: $609-616$

Gaudy R, Boucher J (1983) Relation between respiration, excretion (ammonia and inorganic phosphorus) and activity of amylase and trypsin in different species of pelagic copepods from an Indian Ocean equatorial area. Mar Biol $75: 37-45$

Green JD (1975) Feeding and respiration in the New Zealand Copepod Calamoecia lucasi Brady. Oecologia 21:345-358

Hamburger K, Boëtius F (1987) Ontogeny of growth, respiration and feeding rate of the freshwater calanoid copepod Eudiaptomus graciloides. J Plankton Res 9:589-606

Ikeda $T$ (1977) The effect of laboratory conditions on the extrapolation of experimental measurements to the ecology of marine zooplankton. IV. Changes in respiration and excretion rates of boreal zooplankton species maintained under fed and starved conditions. Mar Biol 41:241-252

Ikeda I (1985) Metabolic rates of epipelagic marine zooplankton as a function of body mass and temperature. Mar Biol 85:1-11

Ikeda T, Motoda S (1978) Estimated zooplankton production and their ammonia exrection in the Kuroshio and adjacent seas. Fish Bull US 76:357-367 
Ikeda T, Skjoldal HR (1989) Metabolism and elemental composition of zooplankton from the Barents Sea during early Arctic summer. Mar Biol 100:173-183

Jacobi CC, Anger K (1985) Effect of temperature on respiration of larval stages of Hyas araneus and $H$. coarctatus (Decapoda, Majidae) Mar Ecol Prog Ser 26:181-186

Jensen LM, Sand-Jensen K, Marcher S, Hansen M (1990) Plankton community respiration along a nutrient gradient in a shallow Danish estuary. Mar Ecol Prog Ser 61:75-85

Kersting K, Van der Leeuw-Leegwater C (1976) Effect of food concentration on the respiration of Daphnia magna. Hydrobiologia 49:137-142

Kiørboe T, Møhlenberg F, Hamburger K (1985) Bioenergetics of the planktonic copepod Acartia tonsa: relation between feeding egg production and respiration and composition of specific dynamic action. Mar Ecol Prog Ser 26:85-97

Lampitt RS, Gamble JC (1982) Diet and respiration of the small planktonic marine copepod Oithona nana. Mar Biol $66: 185-190$

Le Borgne RP (1973) Etude de la respiration et de l'excrétion d'azote et de phosphore des populations zooplanctoniques de l'upwelling mauritanien (mars-avril, 1972). Mar Biol 19 249-257

Le Borgne RP (1979) Influence of duration of incubation on zooplankton respiration and excretion results. J exp mar Biol Ecol 37:127-137

Lehman JT (1980) Release and cycling of nutrients between planktonic algae and herbivores. Limnol Oceanogr 25 $620-632$

Liddicoat ML, Tibbitts S, Butler EI (1975) The determination of ammonia in seawater. Limnol Oceanogr 20:131-133

Margalef $R$, Vives F (1967) La vida suspendica en las aquas In: Ecologia marina. La Salle, Ciencias Naturales, Caracas, p $439-562$

Mayzaud P, Poulet S (1978) The importance of the time factor in the response of zooplankton to varying concentration of naturally occurring particulate matter. Limnol Oceanogr $23: 1144-1154$

Moraitou-Apostolopoulou M (1969) Vertical distribution, diurnal and seasonal migration of copepods in Saronic Bay, Greece. Mar Biol 9:92-98

Moraitou-A postolopoulou M (1974) An ecological approach to the systematic study of planktonic copepods in a polluted area (Saronic Gulf-Greece). Boll Pesca Piscic Idrobiol 29: $29-47$

Moraitou-Apostolopoulou M (1976) Etude comparative du zooplancton superficiel $(0-100 \mathrm{~cm})$ à une zone gravement pollueée et une autre relativement propre igolfe Saronique). Rapp Comm int Mer Médit 23:59-60

Moraitou-Apostolopoulou M (1977) Le zooplancton superfjciel $(0-100 \mathrm{~cm})$ du Golfe Saronique. B. Les Copépodes. Biol Gallo-Hell 7:25-43

Thus article was submitted to the editor
Moraitou-Apostolopoulou M. Kiortsis V (1976) Etude comparée des cladocères du premier metre de l'eau de mer reccueillis dans une zone polluée el dans une autre, relativement propre. Rev int Océanogr Méd 43:37-46

Moraitou-Apostolopoulou M, Verriopoulos G (1976) Laboratory studies on the feeding of Acartia clausi. Boll Pesca Piscic Idrobiol 31:201-208

Moraitou-Apostolopoulou M, Verriopoulos G (1980) Feeding activity of three annual generations of unperturbed and pollution impacted Acartia clausi (Copepoda) populations in Saronicos Gulf (Greece). Rev Int Océanogr Méd 58: 29-39

Omori M. Ikeda $T$ (1984) Methods in marine zooplankton ecology. Wiley \& Sons, New York

Paffenhöfer GA, Gardner WS (1984) Ammonium release by juveniles and adult females of the subtropical marine copepod Eucalanus pileatus. J Plankton Res 6:505-513

Ranta E, Hakala I (1978) Respiration of Mysis relicta. Arch Hydrobiol 83:515-523

Razouls S (1972) Influence des conditions expérimentales sur le taux respiratoire des copépodes planctoniques. J exp mar Biol Ecol 9:145-153

Sarvala J, Ilmavirta V, Paasivirta L, Salonen K (1981) The ecosystem of the oligotrophic lake Paajarvi, 3. Secondary production and an ecological energy budget of the lake. Verh int Verein Limnol 21:454-459

Schneider G (1990) Metabolism and standing stock of the winter mesozooplankton community in the Kiel Bight/ Western Baltic. Ophelia 32:237-247

Schneıder G, Lenz J (1991) Zooplankton community metabolism in the upper $200 \mathrm{~m}$ of the central Red Sea and the Gulf of Aden. Mar Ecol Prog Ser 77:301-306

Schatzlein FC, Costlow JD (1978) Oxygen consumption of the larvae of the decapod crustaceans, Emerita talpoida (Say) and Libinia emarginata Leach. Comp Biochem Physiol 61A:441-450

Sterner RW (1986) Herbivores' direct and indirect effects on algal populations. Science 231:605-607

Strickland JDH, Parsons TR (1972) A practical handbook of seawater analysis. Bull Fish Res Bd Can 167

Tranter DJ, Smith PE (1968) Zooplankton sampling. Monogr Oceanogr Methodol 2:27-56

Utermöhl H (1958) Neue Wege in der Erfassung des Plancktons. Verh int Ver theor Angew Limnol 5:567-596

Uye S, Yashiro M (1988) Respiration rates of planktonic Crustaceans from the Inland Sea of Japan with special refer ence to the effects of body weight and temperature J Oceanogr Soc Japan 44:47-51

Vanni MJ, Findlay DL (1990) Trophic cascades and phytoplankton community structure. Ecology 71:921-938

Zeiss FR (1963) Effects of population densities on zooplankton respiration rates. Limnol Oceanogr 8.110-11.5

Manuscript first received: May 30, 1994

Revised version accepted: April 13, 1995 